JPPKMI 1 (2) (2020)
JURNAL PENELITIAN DAN PENGEMBANGAN
KESEHATAN MASYARAKAT INDONESIA
Jttps://journal.unnes.ac.id/sju/index.php/jppkmi

\title{
Sistem Penyelenggaraan Makanan di Pondok Pesantren Tahfidz
}

\author{
Farohatus sholichah $^{1 凶}$, Fatah Syukur ${ }^{1}$
}

${ }^{1}$ Program Studi Gizi, Fakultas Psikologi dan Kesehatan, UIN Walisongo Semarang, Indonesia

${ }^{2}$ Manajemen Pendidikan Islam, Fakultas Ilmu Tarbiyah dan Keguruan, UIN Walisongo Semarang, Indonesia

\section{Info Artikel}

Sejarah Artikel:

Diterima November 2020

Disetujui November 2020

Dipublikasikan Desember 2020

\section{Keywords:}

The procurement of food, input, proses, output, memorization of Al Qur'an, tahfidz boarding school.

\section{$U R L:$}

https://iournal.unnes.ac.1 d/sju/index.php/ippkmi /article/view/42918

\begin{abstract}
Abstrak
Asupan gizi dapat mempengaruhi kemampuan menghafal Al Qur'an (tahfidz). Pemberian makanan yang tepat dapat diupayakan melalui penyelenggaraan makan. Penelitian ini bertujuan menganalisis input, proses, dan output penyelenggaraan makanan di Pondok Tahfidz Yanbu'ul Qur'an Menawan. Penelitian ini merupakan penelitian kualitatif. Subjek penelitian meliputi pengurus pondok pesantren, tenaga pengelola dan tenaga pelaksana penyelenggaraan makanan, serta santri. Data input dan proses penyelenggaraan makanan diambil dengan wawancara mendalam dan observasi. Data output (tingkat kesukaan) diambil menggunakan kuesioner uji organoleptik. Pengolahan dan analisis data dilakukan dengan content analysis. Hasil penelitian menunjukkan bahwa penyelenggaraan makanan dilakukan secara swakelola sebanyak 3 kali, yaitu makan pagi, makan siang, dan makan malam. Terkait input, anggaran satu kali makan sekitar Rp. 7.000,00/anak. Terkait proses, pondok telah memiliki siklus menu 7 hari. Tidak terdapat menu khusus untuk memperkuat hafalan. Perencanaan kebutuhan, pembelian, dan penerimaan bahan makanan kering dilakukan setiap minggu, sedangkan bahan segar dilakukan setiap hari. Penyimpanan dilakukan pada bahan makanan kering. Persiapan dan pengolahan dilakukan dengan baik. Pendistribusian makanan menggunakan sistem loket (sentralisasi). Terkait output, mutu makanan dapat diterima.
\end{abstract}

\begin{abstract}
Nutritional intake can affect the ability to memorize Al Qur'an (tahfidz). Providing appropriate food can be pursued through the food procurement. This study aims to analyze the food procurement system in Tahfidz Boarding School, Yanbu'ul Qur'an Menawan, including input, process, and output. This research was a qualitative research. The research subjects consisted of boarding school administrators, managing and implementing staff for the food procurement system, and students. The input data and the food processing process were taken by in-depth interviews and observations. The output data in the form of the level of preference were taken using an organoleptic questionnaire. Data processing and analysis was conducted using content analysis. The results showed that the procurement of food was self-managed 3 times, namely breakfast, lunch and dinner. Regarding input, the budget for one meal is around Rp. 7,000.00 / child. Regarding the process, the lodge has a menu cycle of 7 days. There was no special menu to strengthen memorization. Planning for needs, purchasing, and receiving dry food ingredients was carried out every week, while fresh ingredients were carried out every day. Storage was only done for dry food ingredients. Preparation and processing were well done. Food distribution used a counter system (centralization). Regarding output, the quality of food was acceptable.
\end{abstract}

(C) 2020 Universitas Negeri Semarang

\footnotetext{
Alamat korespondensi:

J1. Prof. Dr. Hamka Ngaliyan Semarang, Jawa Tengah 50185.

E-mail: farfar@walisongo.ac.id
} 


\section{PENDAHULUAN}

Menghafal Al Qur'an merupakan tugas paling mulia yang dapat dijalankan oleh seorang Muslim. Menghafal Al Qur'an memiliki beberapa keutamaan. Orang yang membaca satu huruf Al Qur'an akan mendapatkan pahala dan kebaikan, apalagi menghafalnya. Al Qur'an akan datang untuk membela orang yang membaca, menghafal, dan mengamalkannya pada hari kiamat. Selain itu, kedua orang tua penghafal Al Qur'an mendapatkan mahkota pada hari kiamat (Muhsin, 2014).

Asupan gizi juga mempengaruhi kemampuan menghafal, disamping mempengaruhi kesehatan dan pertumbuhan. Kemampuan mengingat dan menghafal dipengaruhi oleh otak kiri (Syarif, 2010). Otak membutuhkan protein, asam lemak esensial, serta berbagai vitamin dan mineral untuk memperbanyak sel syaraf, memperlancar perjalanan saraf (neurotransmitter) dan berbagai aktivitas terkait fungsi otak lainnya (Kemenkes RI, 2002). Selain itu, pada Kitab Ta'limul Muta'allim disebutkan bahwa ketumbar dan apel masam dapat menyebabkan lupa, sedangkan mengurangi makan atau mengurangi pelemakan kulit badan akibat terlalu banyak makan dapat menambah kuat hafalan (As'ad, 2007).

Pemberian makanan yang tepat dapat diupayakan melalui penyelenggaraan makan. Penyelenggaraan makan merupakan rangkaian kegiatan mulai dari perencanaan menu sampai dengan pendistribusian makanan, termasuk kegiatan pencataan, pelaporan, dan evaluasi Prinsip penyelenggaraan makan adalah menyediakan makanan sesuai dengan macam dan kebutuhan zat gizi, disiapkan dengan cita rasa yang tinggi, serta memenuhi syarat hygiene dan sanitasi (Rotua, 2017). Menurut hasil penelitian Ilmi (2014) di Pondok Pesantren Putri Ummul Mukminin Makassar, diketahui bahwa mutu makanan dapat diterima, tetapi nilai gizi makanan terutama energi hanya mencapai sekitar $50 \%$ dari kebutuhan total santri. Tidak jauh berbeda dengan penelitian tersebut, hasil penelitian Taqhi (2014) menunjukkan bahwa mutu makanan di pondok pesantren Hubulo
Gorontalo juga dapat diterima, tetapi nilai gizi makanan terutama energi hanya memenuhi $76 \%$ dari kebutuhan total santri. Hasil penelitian Ningtyias (2018) juga menunjukkan bahwa konsumsi makan santri masih pada kategori defisit karena belum adanya perhitungan kecukupan gizi di pondok pesantren. Di sisi lain, kecukupan energi berpengaruh terhadap peningkatan daya ingat dan daya terima ketika belajar (Nursyaftri, 2014).

Pondok Tahfidz Yanbu'ul Qur'an Menawan merupakan salah satu Pondok Pesantren Tahfidzul Qur'an yang terletak di Kudus. Menurut studi pendahuluan, diketahui bahwa jumlah santri di pondok pesantren tersebut mencapai 750 orang. Pondok pesantren tersebut mensyaratkan hafalan minimal 5 juz sebagai syarat kenaikan kelas. Selama ini, penelitian mengenai sistem penyelenggaraan makanan di Pondok Pesantren Tahfidzul Qur'an belum pernah dilakukan. Oleh karena itu, peneliti tertarik untuk melakukan penelitian mengenai sistem penyelenggaraan makanan di Pondok Tahfidz Yanbu'ul Qur'an Menawan.

\section{METODE}

Penelitian ini merupakan penelitian kualitatif. Penelitian dilaksanakan pada bulan Agustus 2019, di Pondok Tahfidz Yanbu'ul Qur'an Menawan, Kudus. Data input pada penelitian ini adalah biaya penyelenggaraan makan. Data proses terdiri atas perencanaan menu, perencanaan kebutuhan bahan makanan, pembelian bahan, penerimaan bahan makanan, penyimpanan bahan makanan, pengolahan, distribusi, dan penyajian. Sementara itu, data output berupa tingkat kesukaan santri terhadap menu yang disajikan. Subjek penelitian terdiri atas pengurus pondok pesantren, tenaga pengelola dan tenaga pelaksana penyelenggaraan makanan, serta santri. Jumlah sampel sebanyak 52 santri ditentukan dengan random sampling, untuk memperoleh data output penyelenggaraan makanan. Data input dan proses penyelenggaraan makanan diambil dengan wawancara mendalam dan observasi. Data output berupa tingkat kesukaan diambil 
menggunakan kuesioner uji organoleptik. Pengolahan dan analisis data input serta proses penyelenggaraan makanan dilakukan dengan content analysis. Data output penyelenggaraan makanan dianalisis univariat menggunakan aplikasi statistik.

\section{HASIL DAN PEMBAHASAN}

Pengurus pondok pesantren sebagai subjek pada penelitian ini terdiri atas 1 orang pemilik pondok. Sementara itu, tenaga pengelola penyelenggaraan makanan sebagai subjek pada penelitian ini terdiri atas 1 orang koordinator dapur dan 1 orang bendahara. Subjek penelitian yang menjadi tenaga pelaksana penyelenggaraan makan terdiri atas 1 orang kepala juru masak.

Semua subjek penelitian (pengurus dan pengelola) di Pondok Tahfidz Yanbu'ul Qur'an Menawan tidak ada yang berjenis kelamin perempuan. Semuanya berjenis kelamin lakilaki. Hal ini dikarenakan Pondok Tahfidz Yanbu'ul Qur'an Menawan terdiri atas santri yang juga berjenis kelamin laki-laki. Terkait usia, keempat orang subjek penelitian yang terdiri dari pimpinan pondok pesantren serta tenaga pengelola dan pelaksana penyelenggaraan makanan memiliki rentang usia 25-39 tahun. Berdasarkan tingkat pendidikan, pemilik pondok pesantren memiliki tingkat pendidikan Doktor (S3). karakteristik subjek penelitian dapat dilihat pada Tabel 1 .

Terkait ketenagakerjaan, dalam penyelenggaraan makanan terdapat tiga kelompok tenaga kerja yang dibutuhkan yaitu kelompok tenaga pengelola, tenaga pelaksana, dan tenaga pembantu pelaksana. Kelompok tenaga pengelola bertanggung jawab atas perencanaan, pengawasan, dan pengendalian makanan. Kelompok tenaga pelaksana bertanggung jawab terkait pelaksanaan produksi dan distribusi makanan. Kelompok tenaga pembantu pelaksana merupakan kelompok tenaga yang membantu tenaga pelaksana, seperti membersihkan peralatan, membersihkan atau memotong bahan makanan (Rotua, 2017).

Santri yang menjadi sampel dalam penelitian ini adalah sebanyak 52 orang. Terkait karakteristik santri, diketahui bahwa semua santri berjenis kelamin laki-laki. Terdapat 24 dari 52 santri $(46.2 \%)$ berusia 17 tahun. Lainnya, sebanyak 12 santri (23.1\%) berusia 16 tahun dan sebanyak 16 santri (30.8\%) berusia 18 tahun. Karakteristik santri selengkapnya dapat dilihat pada Tabel 2.

Menurut Permenkes RI nomor 25 tahun 2014, batasan usia remaja adalah pada rentang usia 10-18 tahun. Usia mempengaruhi kebutuhan gizi seseorang. Zat gizi yang diperlukan remaja akan menjadi lebih besar disebabkan oleh perubahan tubuh dan organ reproduksi pada remaja. Perubahan fisik, psikis dan kognitif mempengaruhi status gisi remaja (Fikawati, 2017).

Tabel 2 menyebutkan bahwa sampel pada penelitian ini adalah santri berusia 16-18 tahun, sehingga penilaian status gizi dilakukan menggunakan Indeks Massa Tubuh menurut usia (IMT/U). Berdasarkan status gizi menurut IMT/U, diketahui bahwa mayoritas santri atau sebanyak 35 dari 52 santri (67.3\%) memiliki status gizi normal. Lainnya, masing-masing terdapat 1 santri yang memiliki status gizi sangat kurus (1.9\%) dan kurus (1.9\%). Terkait status gizi gemuk dan obesitas, masing-masing

Tabel 1. Karakteristik Subjek Penelitian

\begin{tabular}{|c|c|c|c|c|}
\hline Subjek Penelitian & Jabatan & Usia (Tahun & Jenis Kelamin & Tingkat Pendidikan \\
\hline Pengurus & & 39 & Laki-Laki & Doktor (S3) \\
\hline $\begin{array}{l}\text { Pengelola } \\
\text { Penyelenggaraan } \\
\text { Makanan } \\
\text { Pelaksana }\end{array}$ & $\begin{array}{l}\text { Koordinator } \\
\text { dapur } \\
\text { Bendahara }\end{array}$ & $\begin{array}{l}32 \\
31\end{array}$ & $\begin{array}{l}\text { Laki-Laki } \\
\text { Laki-Laki }\end{array}$ & $\begin{array}{l}\text { Sarjana (S1) } \\
\text { SMA }\end{array}$ \\
\hline $\begin{array}{l}\text { Penyelenggaraan } \\
\text { Makanan }\end{array}$ & $\begin{array}{l}\text { Kepala juru } \\
\text { masak }\end{array}$ & 25 & Laki-Laki & MA \\
\hline
\end{tabular}


Tabel 2. Karakteristik Santri

\begin{tabular}{llll}
\hline Variabel & Kategori & $\mathrm{n}$ & $\%$ \\
\hline Usia (Tahun) & & 12 & 23.1 \\
& 16 & 24 & 46.2 \\
& 17 & 16 & 30.8 \\
Jenis Kelamin & 18 & 52 & 100 \\
& Laki-Laki & & \\
Status Gizi & & 1 & 1.9 \\
& Sangat Kurus & 1 & 1.9 \\
& Kurus & 35 & 67.3 \\
& Normal & 10 & 19.2 \\
& Gemuk & 5 & 9.6 \\
Jumlah (n) & Obesitas & 52 & 100 \\
\hline
\end{tabular}

dijumpai pada 10 orang santri $(19.2 \%)$ dan 5 orang santri $(9.6 \%)$. Hasil penelitian ini sejalan dengan hasil penelitian Amelia, dkk (2013) yang menunjukkan bahwa mayoritas status gizi santri di Yayasan Pondok Pesantren Hidayatullah Makassar juga termasuk dalam kategori normal $88 \%$. Salah satu faktor yang mempengaruhi status gizi adalah asupan gizi. Status gizi merupakan hasil keseimbangan antara asupan makan dengan penyerapan zat gizi dan penggunaan zat gizi. Ketidaktepatan asupan gizi atau adanya penyakit berpengaruh terhadap status gizi (Supariasa, 2016).

Penyelenggaraan makanan di Pondok Tahfidz Yanbu'ul Qur'an harus dapat memenuhi kebutuhan 750 orang santri, terdiri dari santri MTs dan MA. Penyelenggaraan makanan di pondok tersebut dilakukan secara swakelola sebanyak 3 kali dalam satu hari, yaitu makan pagi, makan siang, dan makan malam. Berikut pernyataan dari responden tenaga pelaksana penyelenggaraan makanan:

"Sistemnya beda dengan yang dulu..kalau sebelumnya itu sistem borongan...kalau sekarang ada kepala dan juru masaknya...6 orang, laki-laki semua..." (responden 1$)$

Penyelenggaraan makanan dimulai dari perencanaan menu sampai pendistribusian makanan kepada konsumen, termasuk pencatatan, pelaporan, dan evaluasi demi tercapainya status kesehatan yang optimal dengan ketepatan pemberian makan (Rotua, 2017). Pondok pesantren termasuk salah satu jenis penyelenggaraan makanan institusi yang tidak bertujuan untuk mencari keuntungan, sehingga bersifat non-komersil. Pada umumnya, frekuensi penyediaan makanan yang bersifat non-komersil sebanyak 2-3 kali makan, tanpa adanya selingan sesuai dengan kebijakan institusi tersebut. (Rotua, 2017).

Penyelenggaraan makanan dilakukan dengan sistem swakelola, apabila pihak dapur instalasi bertanggung jawab melaksanakan semua kegiatan penyelenggaraan makan. Penyelenggaraan makanan sistem out-sourching adalah penyelenggaraan makan dengan memanfaatkan pemborong makanan (outsourching), seperti perusahaan jasaboga atau katering (Kemenkes RI, 2018). Kegiatan penyelenggaraan makanan dikelompokkan menjadi tiga tahap, yaitu input, proses, dan output. Manajemen sistem penyelenggaraan makanan berperan dalam pengaturan proses dalam sistem, sehingga ketersediaan input dapat diproses dengan baik menjadi output yang diharapkan.

Hasil penelitian menunjukkan bahwa anggaran makan untuk santri adalah sekitar Rp. 20.000/anak/hari. Oleh karena terdapat tiga kali penyelenggaraan makanan di pondok, yaitu makan pagi, makan siang, dan makan malam, maka anggaran untuk satu kali makan adalah sekitar Rp. 7.000,00/anak. Menurut hasil wawancara, anggaran tersebut bersifat dinamis. Hal ini dikarenakan persediaan bahan makanan dikoordinir oleh pondok pesantren pusat. Pondok Tahfidz Yanbu'ul Qur'an Menawan merupakan salah satu pondok pesantren cabang, dimana distribusi bahan makanan berasal dari pondok pesantren pusat. Kemudian, pondok pesantren pusat akan mengirimkan nota pembelian bahan makanan setiap minggu.

Penggunaan biaya harus sesuai dengan tujuan penyelenggaraan makanan institusi. Penyelenggaraan makanan terbagi menjadi dua tujuan, yaitu profit oriented dan service oriented. Pondok pesantren melakukan penyelenggaraan makanan yang bersifat non komersil, sehingga 
tujuannya adalah memberikan servis (service oriented). Biaya penyelenggaraan makanan yang bertujuan service oriented dapat mencapai 100\% dari total anggaran yang disediakan. Keterbatasan dana memerlukan pengelolaan yang tepat, supaya tetap dapat memenuhi kebutuhan gizi konsumen. Merancang pola menu, macam bahan makanan, jumlah tenaga, jenis menu, serta variasi menu secara tepat merupakan strategi yang dapat dilakukan terkait pengelolaan keterbatasan data (Bakri, 2018). Dana penyelenggaraan makanan berpengaruh terhadap kualitas bahan makanan, sehingga mempengaruhi cita rasa makanan (Agharisty, 2013).

Proses penyelenggaraan makanan terdiri dari beberapa aspek yaitu perencanaan menu, perencanaan kebutuhan bahan makanan, pembelian bahan makanan, penerimaan, penyimpanan, distribusi bahan makanan, persiapan bahan makanan, pengolahan bahan makanan, distribusi makanan, dan penyajian (Rotua, 2017).

Terkait perencanaan menu, pondok pesantren sudah memiliki perencanaan menu makan pagi, siang, dan malam. Perencanaan menu disusun melalui rapat koordinasi antara pengurus pondok, koordinator dapur, dan perwakilan santri yaitu Organisasi Santri Ma'had Yanbu'ul Qur'an Menawan (OSMYQ). Tujuannya, agar diperoleh kesepakatan semua pihak terkait perencanaan menu. Berikut pernyataan subjek penelitian:

"ya ada...menu makannya $3 x$ per hari...terdiri dari makan pagi, makan siang, dan makan malam..."(responden1)

"perencanaan menu itu dari rapat yang melibatkan pimpinan pondok, perwakilan santri yaitu OSMYQ (Organisasi Santri Ma'had Yanbu'ul Qur'an Menawan), dan koordinator dapur atau tukang masaknya...sehingga ada kesepakatan antara pihak-pihak tersebut...misalnya, di malam ahad kami ada menu spesial fried chicken, itu dipesankan dari dari katering luar sesuai permintaan santri, dan kami menerima...sekaligus supaya tukang masaknya ada liburnya...."(responden4)

Terkait siklus menu, hasil penelitian menunjukkan bahwa pondok pesantren sudah memiliki siklus menu. Siklus menu di pondok pesantren tersebut adalah siklus menu 7 hari. Penyusunan siklus menu dilakukan sebanyak 3 kali dalam 1 tahun, yaitu pada setiap pergantian semester sekolah (2 kali) dan menjelang puasa ramadhan. Pada bulan Ramadhan, terdapat menu wajib yaitu minuman dingin dan makanan selingan seperti buah atau kue manis. Di luar kondisi tersebut, pergantian menu sangat jarang dilakukan. Terdapat menu spesial di malam Ahad (Minggu) seperti fried chicken, sesuai permintaan santri dan persetujuan dari pengurus pondok. Berikut pernyataan subjek penelitian:

"siklus menunya 7 hari...dalam 1 tahun ada $3 x$ perubahan menu...di tiap semester KBM (Kegiatan Belajar Mengajar) dan sebelum ramadhan..kalau pas ramadhan itu ditambah request es sama cemilan, cemilannya bisa buah atau brownies...kalau untuk ganti menu di luar itu jarang sekali sih...kondisional kalau itu..."(responden2)

Siklus menu merupakan satu set menu dalam satu hari selama jangka waktu tertentu dan dilaksanakan dalam kurun waktu yang tertentu pula, misalnya siklus menu 3 hari, 4 hari, 10 hari, 1 bulan, atau 1 tahun (Rotua, 2017). Namun, keberadaan siklus menu juga dapat menyebabkan kebosanan apabila siklusnya terlalu singkat. Siklus menu juga dapat menyebabkan kebosanan apabila terdapat kesamaan menu pada hari yang sama di setiap minggu, misalnya pada siklus menu 7 hari (Payne, 2012).

Terkait standar porsi, hasil penelitian menunjukkan bahwa pondok pesantren sudah memiliki standar porsi untuk lauk-pauk. Masing-masing santri mendapatkan 1 porsi lauk-pauk. Begitu juga dengan standar porsi sayur, masing-masing santri mendapatkan 1 sendok sayur. Berbeda dengan lauk dan sayur, pada nasi tidak terdapat standar porsi. Para santri dapat mengambil nasi dengan sistem prasmanan, sesuai keinginan santri.

Mengenai menu khusus untuk mempermudah hafalan, hasil penelitian menunjukkan bahwa tidak terdapat menu khusus yang disajikan pondok pesantren dalam rangka mempermudah hafalan para santri. 
Alasannya, faktor yang berpengaruh terhadap hafalan santri adalah ketekunan santri. Di pondok pesantren tersebut justru tidak diperkenankan amalan khusus, seperti puasa ngrowot. Beberapa amalan yang diharuskan oleh pondok pesantren adalah Puasa Tanggal 1 Rajab, Puasa Tarwiyah Arofah, dan Puasa Muharrom. Namun, amalan-amalan puasa tersebut tidak memiliki keterkaitan dengan hafalan santri. Amalan-amalan puasa tersebut tidak bertujuan untuk memperkuat hafalan. Berikut pernyataan subjek penelitian:

"tidak ada...hafalan memang menjadi syarat kenaikan kelas, minimal $5 \mathrm{juz}$, tapi yang mempengaruhi hafalan adalah ketekunan siswa...di sini tidak diperkenankan puasa ngrowot, yang diharuskan itu puasa rajab tanggal 1, puasa tarwiyah arofah, dan puasa muharram.tapi itu tidak ada keterkaitan dengan hafalan..."(responden1).

Puasa Ngrowot, tidak terdapat istilah sahur dan buka puasa. Para pelaku puasa Ngrowot tetap diperbolehkan makan dalam kesehariannya. Hanya saja, pelaku puasa Ngrowot menghindari makanan pantangan berupa beras dan hasil olahannya (Choiriyah, 2014). Puasa Ngrowot atau bakah adalah puasa dalam artian tidak memakan beras dan hasil olahannya. Pelaku puasa Ngrowot hanya memakan umbi, jagung, dan lainnya sebagai pengganti beras atau hasil olahannya (Faridl, 2007). Puasa Ngrowot dilakukan sekitar tiga tahun lamanya, dengan syarat terlebih dahulu mendapatkan ijazah (izin) dari kyai (Saputra, 2018). Puasa Ngrowot adalah salah satu jenis puasa kebatinan. Puasa kebatinan mempunyai tujuan tersendiri, sesuai dengan ajaran pemimpinnya (Sismono, 2010).

Hasil penelitian ini sejalan dengan teori yang menyatakan bahwa motivasi menghafal merupakan faktor yang mendukung dan meningkatkan kemampuan menghafal $\mathrm{Al}$ Qur'an. Selain tekad yang kuat untuk menghafal, diperlukan juga kaidah utama dalam menghafal Al Qur'an seperti ikhlas, mengetahui nilai amalan, mengamalkan hafalan, meninggalkan dosa, dan berdo'a. Tidak hanya itu, terdapat kaidah utama lainnya seperti memahami makna ayat dengan benar, menguasai ilmu tajwid dengan benar, mengulang-ulang bacaan, dan shalat dengan membaca ayat-ayat hafalan. Hal-hal tersebut dapat membantu memperkuat hafalan Al Qur'an (Muhsin, 2014).

\section{Pada Kitab Ta'limul Muta'allim,} disebutkan bahwa makanan tertentu dapat menyebabkan lupa atau menambah kuat hafalan. Ketumbar dan buah apel masam misalnya, kedua makanan tersebut dapat menyebabkan lupa. Semua makanan atau minuman yang meningkatkan produksi dahak atau lendir, dapat menyebabkan lupa. Terlalu banyak minum air dapat meningkatkan produksi dahak. Sementara itu, terlalu banyak minum air disebabkan karena makan yang terlalu banyak. Oleh karena itu, solusinya adalah dengan mengurangi makan. Mengurangi makan atau mengurangi perlemakan kulit badan karena terlalu banyak makan dapat memperkuat hafalan. Minimalisasi makan adalah salah satu faktor paling kuat dalam mempermudah hafalan (As'ad, 2007). Berbeda dengan teori tersebut, hasil penelitian menunjukkan bahwa di Pondok Tahfidz Yanbu'ul Qur'an Menawan tidak terdapat pola makan khusus yang bertujuan untuk mempermudah hafalan santri.

Perencanaan kebutuhan bahan makanan dilakukan melalui koordinasi dengan pondok pesantren pusat. Penyusunan daftar kebutuhan bahan makanan kering dilakukan per minggu, sedangkan penyusunan daftar kebutuhan bahan makanan segar dilakukan setiap hari. Daftar menu makanan beserta bahan dan beratnya dikoordinasikan dengan pondok pesantren pusat karena pembelian dan pendistribusian bahan makanan dilakukan oleh pondok pesantren pusat. Berikut pernyataan subjek penelitian:

"terkait perencanaan kebutuhan bahan makanan, kami lapor ke pondok pusat, yang di Krandon...kami memberikan daftar menu/ bahanbahan yang harus dibeli selama 1 minggu sekali untuk yang bahan kering, untuk yang bahan basah itu setiap hari...lalu yang melakukan pembelanjaan itu pondok pusat...pondok pusat langsung beli ke Pasar Bitingan.lalu didistribusikan ke kami..."(responden1)

Perencanaan kebutuhan bahan makanan 
merupakan kegiatan menyusun serta menghitung kebutuhan bahan makanan untuk pengadaan makanan di institusi, dengan mempertimbangkan peraturan penyelenggaraan makan pada setiap institusi. Tujuannya adalah untuk efisiensi kebutuhan (Rotua, 2017).

Metode pembelian bahan makanan yang dilakukan pondok pesantren adalah pembelian langsung ke pasar. Namun, pembelian langsung ke pasar tidak dilakukan sendiri oleh pondok pesantren tersebut. Pembelian langsung ke pasar dilakukan oleh pondok pesantren pusat, kemudian didistribusikan ke Pondok Tahfidz Yanbu'ul Qur'an Menawan. Berikut pernyataan subjek penelitian:

"yang melakukan pembelanjaan itu pondok pusat...pondok pusat langsung beli ke Pasar Bitingan..lalu didistribusikan ke

kami..."(responden1)

"kami menerima jadi...yang lebih mengetahui itu petugas pondok pusat...tapi belanjanya pasti dari sumber yang sudah terpercaya...(responden2)"

Pembelian langsung ke pasar dapat dilakukan jika institusi melayani 40 klien. Pada jumlah tersebut, beban penyediaan bahan makanan masih dapat diatasi. Prosedur pembelian dengan metode ini tidak rumit, tetapi kurang memenuhi ketentuan administrasi keuangan yang tetap (Rotua, 2017). Proses pembelian bahan makanan perlu dilakukan sebaik mungkin. Hal ini dikarenakan pada tahap selanjutnya yaitu tahap penerimaan bahan makanan membutuhkan kepastian terkait mutu bahan pangan. Bahan pangan yang diterima harus terjamin kesegaran dan kemanannya (Kwon, 2012).

Tidak terdapat permasalahan pada aspek penerimaan bahan makanan. Jumlah bahan makanan yang diterima dapat memenuhi jumlah kebutuhan santri. Bahkan, biasanya jumlahnya sengaja dilebihkan agar santri tidak mengalami kekurangan asupan. Mutu bahan makanan yang diterima juga sesuai dengan permintaan. Apabila terdapat ketidaksesuaian, akan diupayakan alternatif lain yang sejenis. Berikut pernyataan subjek penelitian:

"ya...sesuai...kalau ada ketidaksesuaian tidak masalah, asalkan ada alternatif lain yang sejenis...misalnya ikan, ikan mas diganti dengan ikan bandeng untuk menu pepes ikan..."(responden2)

Pada proses penerimaan bahan makanan, terdapat beberapa kegiatan yang perlu dilakukan seperti pemeriksaan/penelitian, pencatatan, serta pelaporan kesesuaian bahan makanan yang diterima dengan yang dipesan. Kesesuaian tersebut terkait macam, kuantitas, dan kualitas bahan makanan (Rotua, 2017).

Pondok pesantren sudah memiliki penyimpanan bahan makanan kering dan penyimpanan bahan makanan segar yang telah sesuai standar. Berikut pernyataan dari subjek penelitian:

"ya...ada penyimpanan bahan makanan kering dan basah..."(responden2)

Meskipun terdapat penyimpanan bahan makanan basah, tetapi jarang digunakan karena bahan segar didistribusikan setiap hari. Berikut pernyataan dari subjek penelitian:

"kalau bahan basah atau bahan segar seperti daging atau ikan, sayur, itu malah baru terus habis...langsung diolah semua...langsung didistribusikan setiap hari..."(responden2)

Setelah penerimaan, tahapan proses berikutnya adalah penyimpanan. Penyimpanan bahan makanan terdiri atas tata cara penataan, penyimpanan, pemeliharaan keamanan bahan makanan kering dan basah, serta pencatatan dan pelaporannya. Penyimpanan bahan makanan penting untuk diperhatikan, karena memiliki banyak tujuan yaitu sebagai cara pemeliharaan mutu bahan makanan, perlindungan bahan makanan dari kerusakan kimia, fisik, atau biologis, pemenuhan jenis dan jumlah bahan makanan dengan mutu dan waktu yang tepat (Rotua, 2017). Menurut Nurdianty (2012), penyimpanan bahan makanan sebaiknya menggunakan sistem First In First Out (FIFO). Tujuannya adalah supaya bahan makanan yang digunakan terlebih dahulu adalah bahan makanan yang telah disimpan terlebih dahulu.

Menurut hasil penelitian Mandosir (2017), salah satu permasalahan dalam pengolahan adalah terkadang terdapat ketidaksesuaian antara menu yang disajikan dengan master menu. Berbeda dengan hasil 
penelitian tersebut, hasil penelitian ini menunjukkan bahwa tidak terdapat permasalahan dalam pengolahan bahan makanan. Bahan makanan diolah dengan teknik yang tepat. Bahan makanan yang akan diolah juga masih dalam keadaan segar dan baik. Secara teori, proses pengolahan dilakukan dengan memperhatikan standar porsi, standar bumbu, menu, waktu, prosedur pengolahan, dan durasi pengolahan. Tujuannya, untuk mengubah bahan makanan mentah menjadi makanan siap saji, aman, dan berkualitas (Rotua, 2017). Hasil penelitian ini berbeda dengan hasil penelitian (2017) yang menyatakan bahwa salah satu permasalahan dalam pengolahan adalah terkadang terdapat ketidaksesuaian antara menu yang disajikan dengan master menu.

Pendistribusian makanan dilakukan dengan metode sentralisasi. Sistem yang digunakan adalah sistem loket. Para santri akan antri di loket untuk mendapatkan lauk dan sayur, setelah santri mengambil nasi secara prasmanan. Sistem sentralisasi dilakukan dengan dibantu oleh anggota OSMYQ (Organisasi Santri Ma'had Yanbu'ul Qur'an Menawan). Berikut pernyataan subjek penelitian:

"sentralisasi...dengan sistem loket...petugasnya dibantu oleh anggota OSMYQ (Organisasi Santri Ma'had Yanbu'ul Qur'an Menawan)..."(responden1)

Sistem sentralisasi merupakan sistem distribusi yang paling banyak digunakan karena mempermudah pemantauan kualitas makanan (ketepatan menu, porsi, dan suhu penyajian). Selain itu, sistem ini memerlukan alat yang lebih sedikit daripada sistem desentralisasi. Namun, sistem ini memerlukan waktu penyajian yang lebih lama untuk penyelenggaraan makanan dalam jumlah yang besar (Rotua, 2017).

Penyajian makan dilakukan sebanyak 3 kali. Penyajian makan pagi dilakukan pada pukul 06.00-06.45 WIB, sedangkan persiapannya dimulai pukul 04.00-06.00 WIB. Persiapan makan siang dimulai pukul 09.00-
13.00 WIB dan penyajiannya dilakukan pukul 13.00-13.45 WIB, kecuali hari libur penyajian dilakukan pukul 12.30-13.30. Terkait makan malam, persiapan dilakukan pukul 15.00-16.30 WIB dan disajikan pada pukul 19.30-20.30 WIB. Berikut pernyataan subjek penelitian:

"waktu makan pagi itu jam 06.00-06.45, masak dari jam 04.00-06.00...waktu makan siang ya jam 13.00-13.45, kalau libur makannya jam 12.3013.30..masak dari jam 09.00-sampai sekitar jam 13.00...makan malam jam 19.30-20.30, masaknya dari jam 15.00-16.30..." (responden2)

Terkait peralatan makan, para santri menggunakan alat makan sendiri-sendiri. Berikut pernyataan subjek penelitian:

"wadah bawa sendiri-sendiri..."(responden1)

Peralatan untuk menyajikan hidangan harus terjaga kebersihannya. Menurut hasil penelitian Damayanti (2008), tingkat pencemaran mikroba dan bakteri tinggi pada makanan yang disajikan terbuka. Mengenai penyajian, makanan yang disajikan juga harus dalam wadah yang terpisah. Ketepatan tata hidang merupakan salah satu prinsip dalam penyajian makanan (Kemenkes, 2011). Selain alat penyajian makanan, terdapat aspek lain yang juga perlu diperhatikan yaitu suhu makanan. Hasil penelitian Agustina (2018) menyatakan bahwa terdapat hubungan signifikan antara suhu makanan terhadap sisa lauk yang disajikan. Terkait output penyelenggaraan makanan, hasil uji kesukaan menu dapat dilihat pada Tabel 3.

Pada Tabel 3, diketahui bahwa mayoritas santri menyatakan suka terhadap tekstur menu makan pagi (69.2\%), makan siang (55.8\%), dan makan malam (51.9\%). Santri menyatakan bahwa tekstur makanan tepat dan enak.

Mayoritas santri juga menyukai rasa pada menu makan pagi $(71.2 \%)$ dan menu makan malam (63.5\%). Terkait aroma, mayoritas santri menyukainya pada menu makan pagi $(82.7 \%)$, makan siang (48.1\%), dan makan malam (63.5\%). Begitu juga dengan variasi, mayoritas santri menyatakan suka pada menu makan pagi (73.1\%), makan siang (48.1\%), dan makan malam (61.5\%). Mayoritas santri menyatakan menu sudah bervariasi. Terkait penampilan, 
Tabel 3. Hasil Uji Kesukaan Menu

\begin{tabular}{|c|c|c|c|c|c|c|c|}
\hline \multirow{3}{*}{ Organoleptik } & \multirow{3}{*}{ Kategori } & \multicolumn{6}{|c|}{ Menu Makan } \\
\hline & & \multicolumn{2}{|c|}{ Pagi } & \multicolumn{2}{|c|}{ Siang } & \multicolumn{2}{|c|}{ Malam } \\
\hline & & $\mathbf{n}$ & $\%$ & $\mathbf{n}$ & $\%$ & $\mathbf{n}$ & $\%$ \\
\hline \multicolumn{8}{|l|}{ Tekstur } \\
\hline & Sangat Tidak Suka & 1 & 1.9 & 2 & 3.8 & 1 & 1.9 \\
\hline & Tidak Suka & 9 & 17.3 & 18 & 34.6 & 11 & 21.2 \\
\hline & Suka & 36 & 69.2 & 29 & 55.8 & 27 & 51.9 \\
\hline & Sangat Suka & 6 & 11.5 & 3 & 5.8 & 13 & 25.0 \\
\hline \multicolumn{8}{|l|}{ Rasa } \\
\hline & Sangat Tidak Suka & 0 & 0 & 2 & 3.8 & 0 & 0 \\
\hline & Tidak Suka & 9 & 17.3 & 25 & 48.1 & 8 & 15.4 \\
\hline & Suka & 37 & 71.2 & 22 & 42.3 & 33 & 63.5 \\
\hline & Sangat Suka & 6 & 11.5 & 3 & 5.8 & 11 & 21.2 \\
\hline \multicolumn{8}{|l|}{ Aroma } \\
\hline & Sangat Tidak Suka & 0 & 0 & 3 & 5.8 & 1 & 1.9 \\
\hline & Tidak Suka & 7 & 13.5 & 22 & 42.3 & 10 & 19.2 \\
\hline & Suka & 43 & 82.7 & 25 & 48.1 & 33 & 63.5 \\
\hline & Sangat Suka & 2 & 3.8 & 2 & 3.8 & 8 & 15.4 \\
\hline \multicolumn{8}{|l|}{ Variasi } \\
\hline & Sangat Tidak Suka & 0 & 0 & 1 & 1.9 & 0 & 0 \\
\hline & Tidak Suka & 11 & 21.2 & 22 & 42.3 & 12 & 23.1 \\
\hline & Suka & 38 & 73.1 & 25 & 48.1 & 32 & 61.5 \\
\hline & Sangat Suka & 3 & 5.8 & 4 & 7.7 & 8 & 15.4 \\
\hline \multicolumn{8}{|l|}{ Penampilan } \\
\hline & Sangat Tidak Suka & 1 & 1.9 & 4 & 7.7 & 1 & 1.9 \\
\hline & Tidak Suka & 19 & 36.5 & 21 & 40.4 & 12 & 23.1 \\
\hline & Suka & 29 & 55.8 & 25 & 48.1 & 34 & 65.4 \\
\hline & Sangat Suka & 3 & 5.8 & 2 & 3.8 & 5 & 9.6 \\
\hline \multicolumn{8}{|l|}{ Penayajian } \\
\hline & Sangat Tidak Suka & 0 & 0 & 1 & 1.9 & 1 & 1.9 \\
\hline & Tidak Suka & 19 & 36.5 & 15 & $28 . .8$ & 10 & 19.2 \\
\hline & Suka & 27 & 51.9 & 31 & 59.6 & 33 & 63.5 \\
\hline & Sangat Suka & 6 & 11.5 & 5 & 9.6 & 8 & 15.4 \\
\hline TOTAL & & 52 & 100 & 52 & 100 & 52 & 100 \\
\hline
\end{tabular}

mayoritas santri menyatakan suka pada menu makan pagi (55.8\%), makan siang $(48.1 \%)$, dan makan malam $(65.4 \%)$. Begitu pula dengan penyajian, mayoritas santri menyukai penyajian menu makan pagi (51.9\%), makan siang (59.6\%), dan makan malam (63.5\%).

Organoleptik makanan terdiri atas warna, aroma, tekstur, dan rasa. Pengukuran sifat fisik dan organoleptik seperti warna, bentuk, aroma, rasa, dan tekstur perlu dilakukan karena sifat-sifat tersebut berpengaruh terhadap penampilan dan daya terima produk. Rasa yang enak akan mempengaruhi sisa makanan yang semakin sedikit (Anwar, 2012). Menurut hasil penelitian Kaenong (2014), rasa dan aroma yang kurang baik dapat menyebabkan santri kurang menyukai makanan yang disajikan. Tidak hanya cita rasa, kepuasan juga 
dipengaruhi oleh penampilan yang menarik (Kustiyoasih, 2016). Selain itu, Menurut hasil penelitian Sholihah (2013) di Pondok Pesantren Hidayatullah Makassar, pola konsumsi santri juga dipengaruhi oleh siklus menu dan variasi makanan, terutama pada lauk dan sayur. Menurut hasil penelitian Atikah (2014), variasi berbagai macam rasa pada suatu makanan lebih disukai, daripada hanya terdiri atas satu rasa.

\section{PENUTUP}

Tidak dijumpai permasalahan terkait sistem penyelenggaraan makanan yang meliputi input, proses, dan output. Mengenai menu khusus terkait hafalan Al Qur'an, tidak terdapat menu khusus yang disajikan pondok pesantren dalam rangka mempermudah hafalan para santri.

Bagi penelitian selanjutnya, disarankan untuk dapat melakukan penelitian dengan metode yang lain. Selain itu, penambahan variabel juga dapat dilakukan supaya dapat menambah informasi hasil penelitian terkait sistem penyelenggaraan makanan di pondok pesnatren tahfidz.

\section{DAFTAR PUSTAKA}

Agharisty, E. 2013. Analisis Biaya dan Analisis Zat Gizi pada Penyelenggaraan Makanan di Sekolah Polisi Negara (SPN) Batua Kota Makassar Sulawesi Selatan Tahun 2013. Media Gizi Pangan, 16 (1):7-9.

Agustina, Lilis dan Suzanna Primadona. 2018. Hubungan antara Rasa Makanan dan Suhu Makanan dengan Sisa Makanan Lauk Hewani Pada Pasien Anak di Ruang Rawat Inap RUMKITAL Dr. Ramelan Surabaya. Jurnal Gizi Indonesia 2018, 3(2):245-253.

Amelia, A., Syam, A., St. Fatimah. 2013. Hubungan Asupan Energi dan Zat Gizi dengan Status Gizi Santri Putri Yayasan Pondok Pesantren Hidayatullah Makassar Sulawesi Selatan Tahun 2013. Jurnal Universitas Hasanuddin Makassar.

Anwar, I., Herianandita, E. \& Ruslita, I. 2012. Evaluasi Sistem Penyelenggaraan Makanan Lunak dan Analisis Sisa Makanan Lunak di
Beberapa Rumah Sakit di DKI Jakata, Tahun 2011. Jurnal Gizi Indonesia, 35(2): 97-108

As'ad, Aliy. 2007. Terjemah Ta'limul Muta'allim. Kudus: Menara Kudus.

Atikah, Sinti Nisa. Setiawan, Budi. 2014. Analisis Kinerja Penyelenggaraan Makanan dan Tingkat Kepuasan Konsumen Restoran Khas Padang di Bogor. Jurnal Gizi dan Pangan, 9(1): 59-64.

Bakri, Bachyar, Ani Intiyani, dan Widartika. 2018. Sistem Penyelenggaraan Makanan Institusi. Jakarta: Kementerian Kesehatan Republik Indonesia.

Damayanti, E., Yuliati, L., Suprapti, V., Sari, F. 2008. Aspek Sanitasi dan Higiene di Kantin Asrama Tingkat Persiapan Bersama IPB. Jurnal Gizi dan Pangan, 3(1): 22-29.

Ilmi, Nurul., Dachlan, Djunaidi., Yustini. 2014. Sistem Sistem Penyelenggaraan Makanan di Pondok Pesantren Putri Ummul Mukminin Makassar. Jurnal Universitas Hasanuddin Makassar.

Kaenong, Khaerul Muthiah., M. Dachlan, Djunaidi., Salam, Abdul. 2014. Gambaran Asupan Zat Gizi Makro, Status Gizi, dan Tingkat Kepuasan Santri Pada Sistem Penyelenggaraan Makanan di Pondok Pesantren Putri Ummul Mukminin Makassar. Makassar: Universitas Hasanuddin Makassar.

Kemenkes RI. 2011. Peraturan Menteri Kesehatan Nomor 1096/Menkes/Per/VI/2011 tentang Higiene Sanitasi Jasaboga. Jakarta: Kementerian Kesehatan RI.

Kemenkes RI. 2018. Manajemen Sistem Penyelenggaraan Makanan Institusi

Kustiyoasih, M.P., Adriani, M., Nindya, T.S. 2016. Penyelenggaraan Makanan dan Kepuasan Konsumen di Kantin Lantai 2 Rumah Sakit Universitas Airlangga Surabaya. Media Gizi Indonesia, 11(1): 11-16.

Kwon,S., Bednar, CM., Junehee, K., Butler, KA. 2012. An Investigation of College and University Food Service Administrator's Level of Agreement on Potensial Influencing Factors on Sustainable Food Waste Management. Journal of Food Service Management and Education, 6(2): 21-26.

Mandosir, Y.M., Sinaga, E. 2017. Analisis Sistem Penyelenggaraan Makan SMA Negeri Khusus Olahraga (SMANKOR) PAPUA. Jurnal Pendidikan Jasmani Olahraga dan Kesehatan, 3(1):19-34. 
Muhsin, Abdul dan As-Sirjani, Raghib. 2014. Orang Sibuk pun Bisa Hafal Al Qur'an. Solo: PQS Publishing.

Ningtyias, F., Prasetyowati, I., Astuti, I., Muslicha, S., Nafi', A., Haryono, A. 2018. Gambaran Sistem Penyelenggaraan Makanan Pondok Pesantren, Kabupaten Jember. Medical Technology and Public Health Journal (MTPH Jurnal), 2(1): 25-34.

Nurdianty, Radhiyah, Daetilan DM, Nawir, N. 2012. Penyelenggaraan Makanan dan Tingkat Kepuasan Atlet di Pusat Pendidikan dan Latihan Pelajar Dinas Pendidikan Pemuda dan Olahraga Makassar. Media Gizi Masyarakat Indonesia, 1(2): 91-96.

Nursyaftri, et al. 2014. Kebiasaan Sarapan dan Kemampuan Menghafal Al-Quran di Pondok
Pesantren Moderen Ulul Albab Kelurahan Sudiang Raya Kecamatan Biringkanaya Kota Makassar. Jurnal Media Gizi Pangan; 18(2).

Rotua, Manuntun dan Siregar, Rohanta. 2017. Manajemen Sistem Penyelenggaraan Makanan Institusi Dasar. Jakarta: EGC.

Sholiha, YA. 2013. Gambaran Pola Konsumsi dan Tingkat Kepuasan Santri Putri terhadap Hidangan di Yayasan Pondok Pesantren Hidayatullah Makassar. Media Gizi Pangan, 15(1): 5-7.

Syarif, Chatrine. 2010. Menjadi Pintar dengan Otak Tengah. Yogyakarta: PT Buku Kuta.

Taqhi, ST. Aisyah., Dachlan, Djunaidi., St. Fatimah. 2014. Sistem Sistem Penyelenggaraan Makanan di Pondok Pesantren Hubulo Gorontalo. Jurnal MKMI: 241-247. 